\title{
Folic Acid Status in Normal Infants During the First Year of Life
}

\author{
T. M. VANIER and J. F. TYAS \\ From the Department of Haematology, St Thomas' Hospital and Medical School, London S.E.1
}

This study was carried out in normal infants living in London in order (a) to obtain normal figures for parameters related to folic acid metabolism in this age-group, and (b) to see if by adult criteria there was any evidence in such infants of folic acid deficiency.

\section{Material and Methods}

Twenty-four normal full-term infants born in St Thomas' hospital were followed during the first year of life. All but 5 were firstborn. Selection of cases was mainly on the basis of the mother being able and willing to co-operate. 3 mothers were patients attending regularly in other departments of the hospital and most of the others lived within easy walking distance. In some cases tests were carried out at home. The exact nature of the study was explained and only 10 of the 40 mothers originally approached were unwilling to take part. 6 more were unable to continue for the whole year.

In the mothers, serum and whole blood folate $(L$. casei) levels were estimated between 3 and 6 days after delivery. All but one mother had received between 100 and $130 \mathrm{mg}$. folic acid prophylactically during the third trimester of pregnancy. In all but 4 the last dose of folic acid had been taken more than a week before blood samples were obtained.

In the infants the following tests were carried out between the ages of 3 and 6 days, 3 and 4 months, 6 and 8 months, and finally at about the age of 1 year: serum (or plasma) and whole blood folate (L. casei), formiminoglutamic acid (Figlu) and urocanic acid excretion after a histidine load, haemoglobin, haematocrit (PCV), and neutrophil lobe count.

In the mothers, venous blood samples were taken at least 3 hours after breakfast and before lunch. In the infants blood was usually obtained by heel-prick. Ethylene-diamine-tetra-acetate (EDTA) was used as the anticoagulant.

Serum (or plasma) and whole blood folate. Folate activity of plasma and serum was shown by Herbert (1961) to be essentially the same, and this has been our experience. In most infants and in some

Received March 9, 1966. mothers plasma was assayed instead of serum. In the neonatal period just visible haemolysis was occasionally noted in blood samples; but plasma levels were accepted in spite of this, since we have found that, despite much higher red cell folate content, slight haemolysis does not significantly influence serum/plasma levels unless these are subnormal.

Serum or plasma was assayed as described by Chanarin and Berry (1964), using a $1: 100$ extract in ascorbate phosphate buffer.

Whole blood after careful mixing was diluted $1: 40$ in $0.1 \mathrm{M}$ phosphate buffer (and later in distilled water, since we found this made no difference to results), containing $30 \mathrm{mg}$. ascorbic acid per ml. blood used. The $p \mathrm{H}$ was then adjusted to between 6 and 7, using $1 \mathrm{~N}$ or $0.25 \mathrm{~N} \mathrm{NaOH}$, and the sample incubated for 2 hours at $37^{\circ} \mathrm{C}$. The sample was then deep frozen until the day of assay. After unfreezing, whole blood was further diluted to 1 : 400 in ascorbate phosphate buffer before autoclaving. We have found that dilutions of $1: 200$, $1: 400$, and $1: 800$ give similar results, but that generally $1: 400$ gives a better reading on the standard curve. Results have been expressed as 'folate activity of whole blood per ml. red cells'. This figure is obtained by the following formula:

Whole blood folate - serum folate

$$
\frac{\text { PCV }}{100}+\text { serum folate. }
$$

In our hands the error of the $L$. case $i$ assay may be as high as $10 \%$ for serum levels and $15 \%$ for whole blood levels in assays carried out on different days, and half these figures for duplicate samples in the same assay.

Food folate. Solid or semisolid food ( 1 g.) was homogenized in $20 \mathrm{ml} .0 \cdot 1 \mathrm{M}$ phosphate buffer at $p H$, containing $150 \mathrm{mg}$. ascorbic acid per $100 \mathrm{ml}$. Liquid foods were added to the buffer just before autoclaving. Final dilutions for autoclaving were of the order $1: 40$ to $1: 400$ of the sample thus obtained. An aliquot was also subjected to charcoal adsorption as follows: $4 \mathrm{ml}$. were added to $16 \mathrm{mg}$. activated charcoal, shaken well, and left at room temperature for 20 minutes. After centrifuging, the supernatant was assayed at the same time as the unadsorbed sample. The resulting figure for 'folate activity' was deducted from that of the unadsorbed sample. Charcoal adsorption, by removing folates from 


\section{Folic Acid Status in Normal Infants During the First Year of Life}

the supernatant, allows an estimate to be made of other substances likely to enhance growth of the assay organism (Butterworth, Santini, and Frommeyer, 1963; Snell and Peterson, 1940).

\section{Urine Figlu and urocanic acid.}

Dose of histidine. In adults it is usual practice to give the same dose of histidine for loading, regardless of body weight. The dose is generally of the order of 200-300 mg./kg. Hansen (1964) has shown that increasing doses of histidine result in an increase of Figlu excretion in normal subjects. Widely different doses have been used in loading infants and children (Dormandy, Waters, and Mollin, 1963, Friedman, McKenzie, Turner, and Wittmann, 1964a ; Frézal, Rey, Jarlier, and Lamy, 1964), and these have not always been closely related to weight or size, and generally involve a higher dose/weight than in even a light-weight adult.

Expressed per $\mathrm{kg}$. body weight the protein intake of adequately nourished infants is nearly 3 times that of adults, but expressed on the basis of surface area the intakes are similar. It is possible therefore to argue in two ways: either that an infant should be able to handle three times as much protein (and therefore histidine) for his weight, or that an infant is already having three times as much histidine in his diet weight for weight and therefore cannot handle as much as an adult when given as a 'load'.

We tested two normal full-term infants at the ages of 2 and 3 months respectively, making use of different histidine loads. Tests were carried out at 4- to 7-day intervals. Urine samples were obtained before each test, and none contained detectable amounts of Figlu or urocanic acid. Both infants had normal serum folates and lobe counts. In both cases there was an increase in metabolite excretion as the dose of histidine was raised, and at a dose of $500 \mathrm{mg}$. $/ \mathrm{kg}$. one infant excreted 'pathological' amounts of Figlu. In neither case did excretion return to the lower levels following 14 days on $1 \mathrm{mg}$. folic acid daily. A normal adult, who for the purposes of the test took $100 \mathrm{mg}$. folic acid during the preceding 2 months, excreted urocanic acid on a histidine load of
$500 \mathrm{mg} . / \mathrm{kg}$. but not on a load of $250 \mathrm{mg}$. $/ \mathrm{kg}$., though Figlu excretion did not vary (Table I).

It was felt, therefore, that whatever the theoretical capacity for handling histidine, in practice an increased load led to increased excretion of one or both metabolites which might not be completely corrected by folic acid. In this our experience differed from that of Friedman et al. (1964a) and Frézal et al. (1964), but it should be noted that the latter were dealing with sick children admitted to hospital. Additional considerations in deciding on the loading dose were (1) that as little as $100 \mathrm{mg}$. histidine per $\mathrm{kg}$. was sufficient to provoke abnormal Figlu excretion in sick or premature infants with other criteria of folate deficiency, and (2) that the smaller the dose offered the more likely was it to be swallowed and retained.

Since doses up to $300 \mathrm{mg} . / \mathrm{kg}$. did not provoke 'pathological' excretion of metabolites by adult standards, the infants in this study were divided into three groups: 10 received $100 \mathrm{mg}$. $/ \mathrm{kg}$., 5 received $200 \mathrm{mg}$. $/ \mathrm{kg}$., and 9 received $300 \mathrm{mg} . / \mathrm{kg}$. In newborn infants this was given in a small quantity of milk or water and in older infants in raspberry syrup.

Time of collection. Since it is difficult in young infants to ensure that urine collection over a given time is complete, results have been expressed as the concentration of metabolites in the urine collected and not as the total amount excreted. In 6 infants at different ages, collections were carried out for $\mathbf{1 2}$ hours (and in $\mathbf{2}$ for as long as 24 hours). Fig. 1 and 2 show that excretion reaches a maximum between 4 and 8 hours after taking histidine and that the peak of excretion is reached at the end of 6 hours. As a matter of convenience, collection was started from the time histidine was given and continued for the shortest possible time compatible with accurate results. This we judged to be for six hours. In most cases a sample of urine just before loading was available. In only 2 infants were detectable amounts of Figlu present in these specimens, in one infant at 6 days and in another at 3 months.

Estimation of Figlu and urocanic acid. These substances were measured semiquantitatively using high

TABLE I

Effect of Increasing Doses of Histidine on Figlu and Urocanic Acid Excretion

\begin{tabular}{|c|c|c|c|c|c|c|c|c|c|c|}
\hline & & \multirow{2}{*}{$\begin{array}{l}\text { Weight } \\
\text { (kg.) }\end{array}$} & \multirow{2}{*}{$\begin{array}{l}\text { Surface } \\
\text { Area } \\
\text { (sq. m.) }\end{array}$} & \multicolumn{2}{|c|}{ Histidine } & \multirow{2}{*}{$\begin{array}{l}\text { 6-hr. } \\
\text { Urine } \\
\text { Volume }\end{array}$} & \multicolumn{2}{|c|}{ Figlu } & \multicolumn{2}{|c|}{ Urocanic Acid } \\
\hline & & & & mg./kg. & g. $/ 1 \cdot 73$ sq. m. & & $\mu \mathrm{g} . / \mathrm{ml}$ & mg./6 hr. * & $\mu \mathrm{g} . / \mathrm{ml}$ & mg./6 hr. * \\
\hline $\begin{array}{l}\text { Female infant ( } 2 \text { mth.) } \\
\text { After folic acid } \quad \text {. }\end{array}$ & $\cdots$ & $5 \cdot 1$ & $0 \cdot 29$ & $\begin{array}{l}100 \\
200 \\
500 \\
500\end{array}$ & $\begin{array}{l}3 \\
6 \cdot 1 \\
15 \\
15\end{array}$ & $\begin{array}{r}90 \\
100 \\
50 \\
70\end{array}$ & $\begin{array}{r}25 \\
50 \\
1500 \\
400\end{array}$ & $\begin{array}{l}2 \cdot 25 \\
5 \\
75 \\
28\end{array}$ & $\begin{array}{r}0 \\
0 \\
100 \\
100\end{array}$ & $\begin{array}{l}0 \\
0 \\
5 \\
5\end{array}$ \\
\hline $\begin{array}{l}\text { Male infant ( } 3 \mathrm{mth} .) \\
\text { After folic acid } \ldots\end{array}$ &. & $5 \cdot 5$ & $0 \cdot 3$ & $\begin{array}{l}100 \\
300 \\
500 \\
500\end{array}$ & $\begin{array}{r}3 \cdot 2 \\
9 \cdot 5 \\
15 \cdot 9 \\
15 \cdot 9\end{array}$ & $\begin{array}{r}110 \\
90 \\
75 \\
120\end{array}$ & $\begin{array}{r}0 \\
0 \\
50 \\
50\end{array}$ & $\begin{array}{l}0 \\
0 \\
3 \cdot 8 \\
6\end{array}$ & $\begin{array}{r}0 \\
0 \\
100 \\
100\end{array}$ & $\begin{array}{l}0 \\
0 \\
7 \cdot 5 \\
12\end{array}$ \\
\hline Normal adult & $\cdots$ & 62 & $1 \cdot 73$ & $\begin{array}{l}250 \\
500\end{array}$ & $\begin{array}{l}15 \\
30\end{array}$ & $\begin{array}{l}500 \\
500\end{array}$ & $\begin{array}{l}25 \\
25\end{array}$ & $\begin{array}{l}12 \cdot 5 \\
12 \cdot 5\end{array}$ & $\begin{array}{r}0 \\
50\end{array}$ & $\begin{array}{r}0 \\
25\end{array}$ \\
\hline
\end{tabular}

* Approximate figures in infants since urine collection may have been incomplete. 


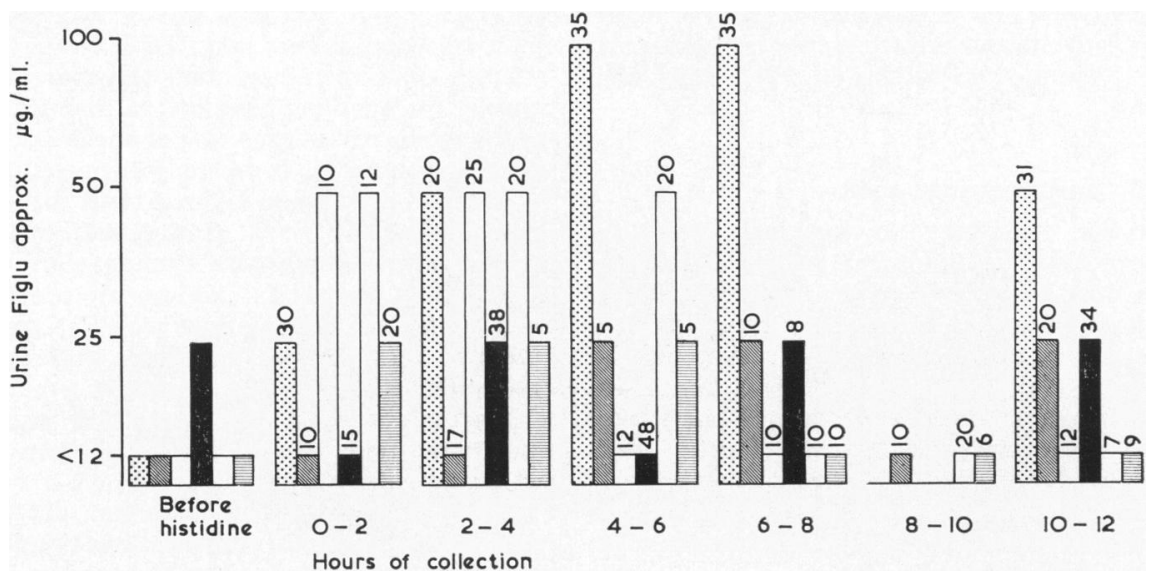

Fig. 1.-Urinary excretion of Figlu in 6 infants ranging in age from 3 days to 1 year. The figures at the top of each column refer to the volume (ml.) of urine collected. The infant with an excretion of $100 \mu \mathrm{g} . / \mathrm{ml}$. was ill and is not included in this series.

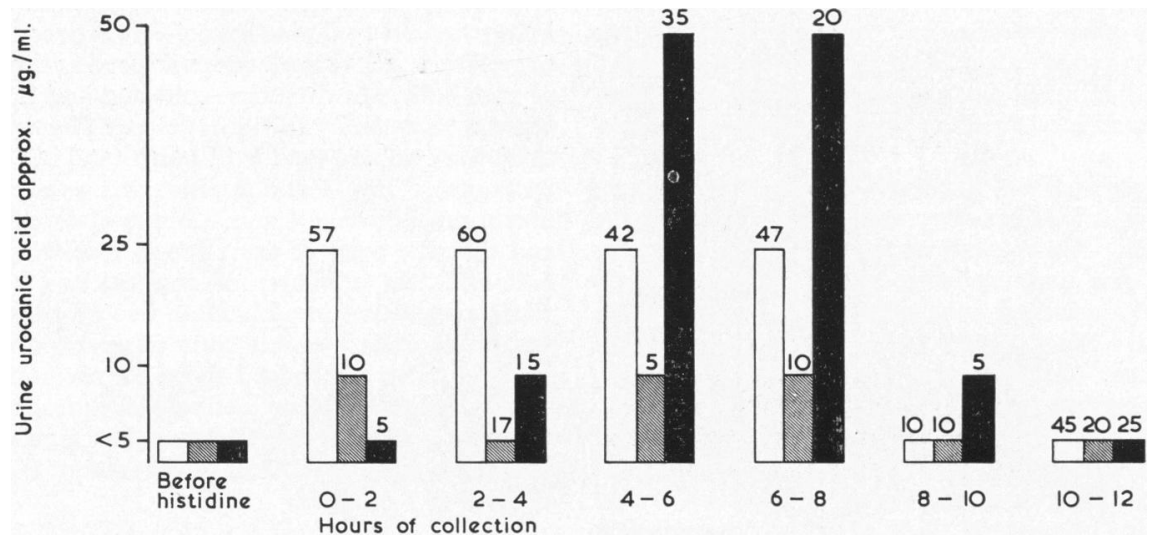

Fig. 2.-Urinary excretion of urocanic acid in 3 infants at 3 days, 6 months, and 1 year. The figures at the top of each column refer to the volume $(\mathrm{ml}$.) of urine collected.

voltage electrophoresis. The method was modified from that of Knowles, Prankerd, and Westall (1960). A dissociated buffer system was used (pyridine/acetic acid $p \mathrm{H} 5.3$ and citric/phosphate $p \mathrm{H} \mathrm{6.4)}$. As little as 12.5 $\mu \mathrm{g} . / \mathrm{ml}$. Figlu and $10 \mu \mathrm{g} . / \mathrm{ml}$. urocanic acid could be detected in this way. Ninhydrin was used to identify Figlu and Pauly's sulphanilic acid reagent to identify urocanic acid.

Neutrophil lobe count. The number of lobes in each of one hundred neutrophil polymorphs was recorded and expressed as the average number of lobes per cell and as the percentage of cells with 5 or more lobes.

\section{Results}

Maternal and neonatal folate levels. In the neonatal period infants generally had higher serum and whole blood folate levels than their mothers (Fig. 3). The 4 mothers with serum levels over $20 \mathrm{~m} \mu \mathrm{g} . / \mathrm{ml}$. had all received a dose of folic acid within the preceding week. In all 4, the infant had a serum level below that of his mother, but in only 2 did he have a whole blood level below that of his mother. At birth or shortly afterwards the difference between mothers' and infants' blood levels is usually greater (Grossowicz, Aronovitch, Rachmilewitz, Izak, Sadousky, and Bercouici, 1960; Baker, Frank, Pasher, Ziffer, and Sobotka, 1960), but the fact that prophylactic folic acid was given to the mothers in this study during pregnancy probably accounts for our relatively higher maternal levels. 


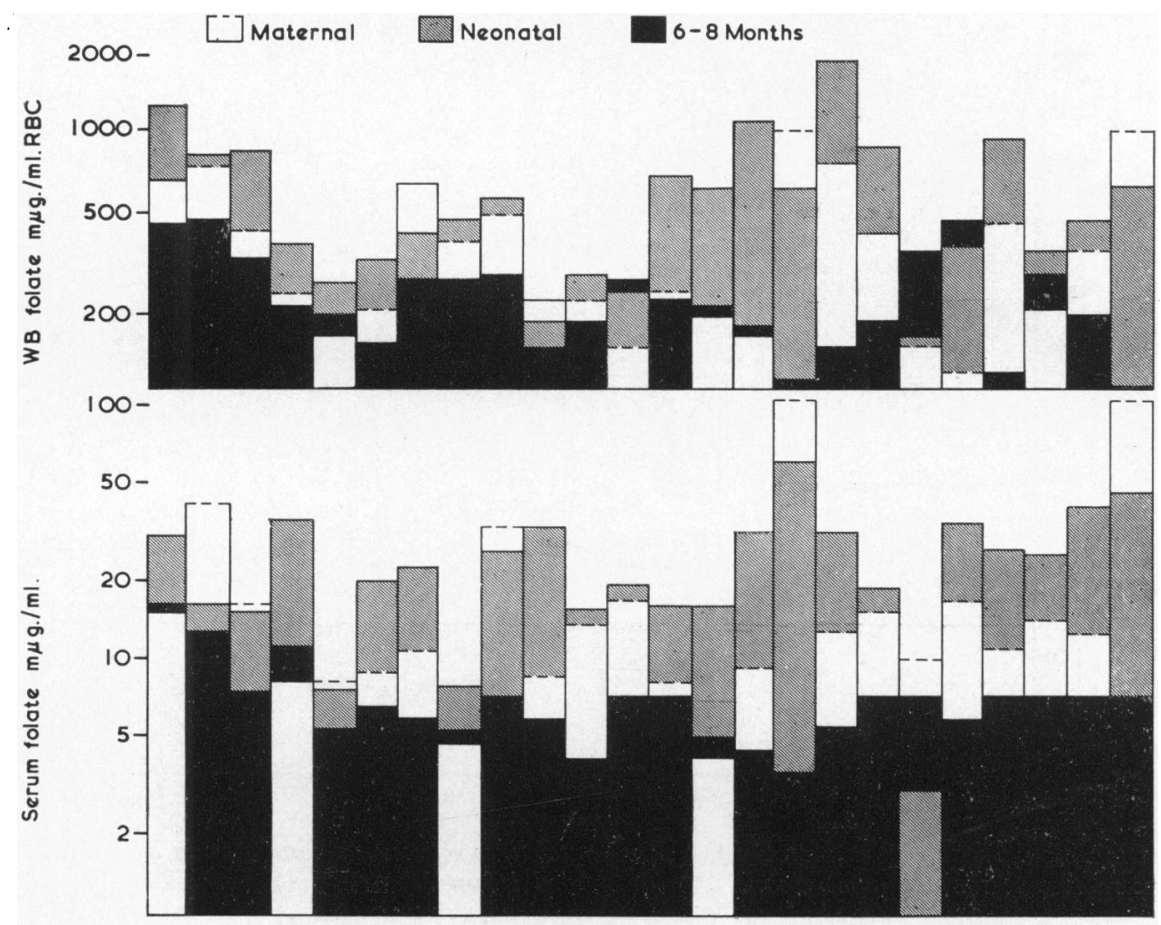

FIG. 3.-Maternal, neonatal, and 6-8-month serum and whole blood (L. casei) folate levels.

Folic acid status from the neonatal period to I year. Table II lists the changes in weight, haemoglobin, MCHC, serum folate, whole blood folate, whole blood folate expressed per ml. red cells, and neutrophil lobe counts during the first year of life.

Folate levels (Fig. 4 and 5). By the time infants were 3 months old there had been a marked fall in serum and whole blood folate. Mean values remained below those of adults during the first year. Only 2 infants had been breast fed for the first 3 months and both had higher serum and whole blood levels. The same 2 infants at 6 and 12 months had levels just below the mean for age. The infant with a high serum and whole blood level at 1 year had been given a proprietary food containing folic acid for three weeks during the month preceding the test but had received none for a week before the blood sample was taken.

Between the ages of 6 and 8 months, 2 infants were found to have serum folate levels of 3.5 and $4.3 \mathrm{~m} \mu \mathrm{g}$. $/ \mathrm{ml}$., which are low by adult standards. At the age of 1 year, 1 of these infants and 2 others had levels of 3,4 , and $4 \mathrm{~m} \mu \mathrm{g}$. $/ \mathrm{ml}$., respectively. In three instances the whole blood folate was below the mean for that age, but lower levels were recorded in other infants with normal serum levels. In only one instance did the infant have a slight increase in neutrophil segmentation and this may have been associated with some degree of iron deficiency. There was no increase in Figlu or urocanic acid excretion.

Because the occasional normal subject has a low whole blood $L$. casei level without any other indication of folate or B12 deficiency (Hansen, 1964; Vanier and Tyas, 1966), we have found it difficult to evaluate whole blood levels in terms of folic acid deficiency unless they are very low indeed. If, however, we were to discount the one subject in our normal adult series with a whole blood level per ml. red cells of less than $100 \mathrm{~m} \mu \mathrm{g}$., then 2 infants at the age of 1 year had low levels by adult standards: 74 and $92 \mathrm{~m} \mu \mathrm{g} . / \mathrm{ml}$., respectively. Neither of these had low serum levels, but 1 had $4 \%$ of 5 lobed neutrophils.

Excretion of Figlu and urocanic acid (Fig. 6). Excretion of these metabolites following histidine load varied between ' 0 ' (less than $10 \mu \mathrm{g}$. $/ \mathrm{ml}$. of urocanic acid and $12.5 \mathrm{~m} \mu \mathrm{g} . / \mathrm{ml}$. Figlu) and $50 \mathrm{~m} \mu \mathrm{g}$./ $\mathrm{ml}$. The dose of histidine between 100 and $300 \mathrm{mg}$. $/$ 


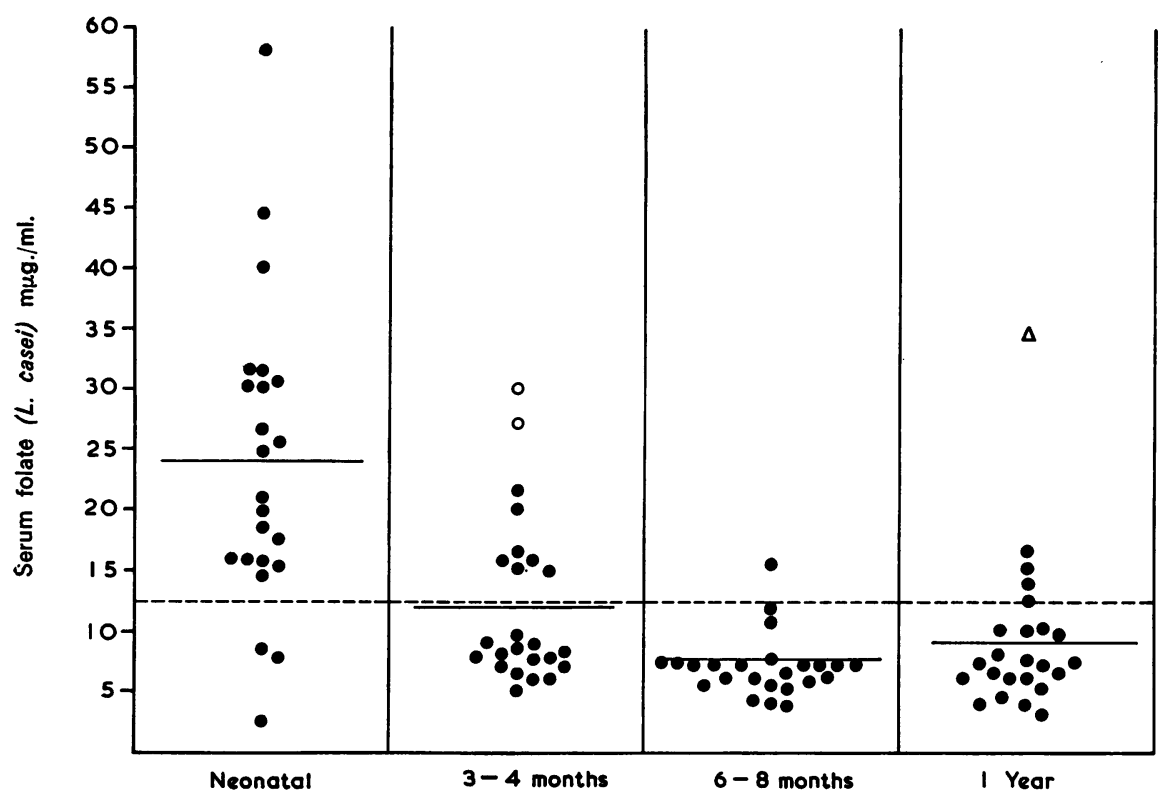

Fig. 4.-Serum folate during the first year of life. Horizontal lines represent mean figure in each age-group. Broken horizontal line represents normal adult mean. $\bigcirc$ Breast-fed infants. $\triangle$ Infant who had received folate-fortified proprietary food.

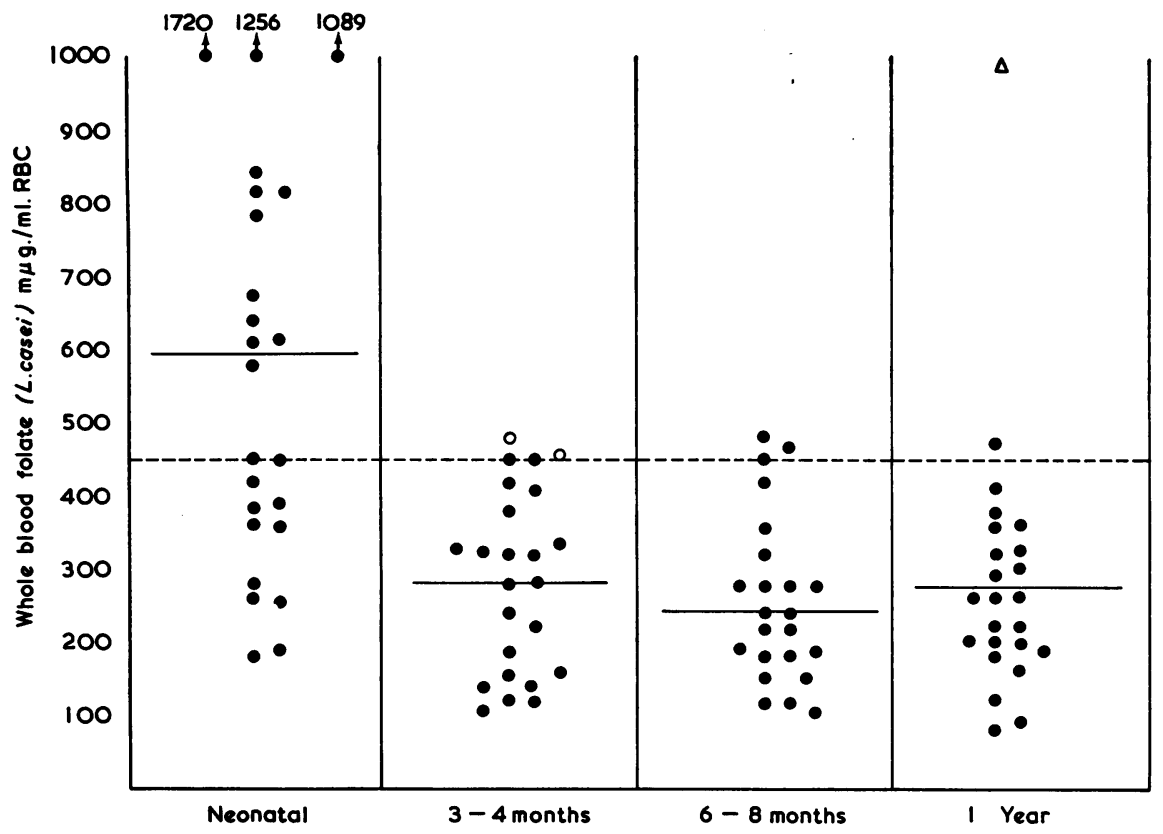

Fig. 5.-Whole blood folate (expressed per ml./RBC) during the first year of life. Key as in Fig. 4. 


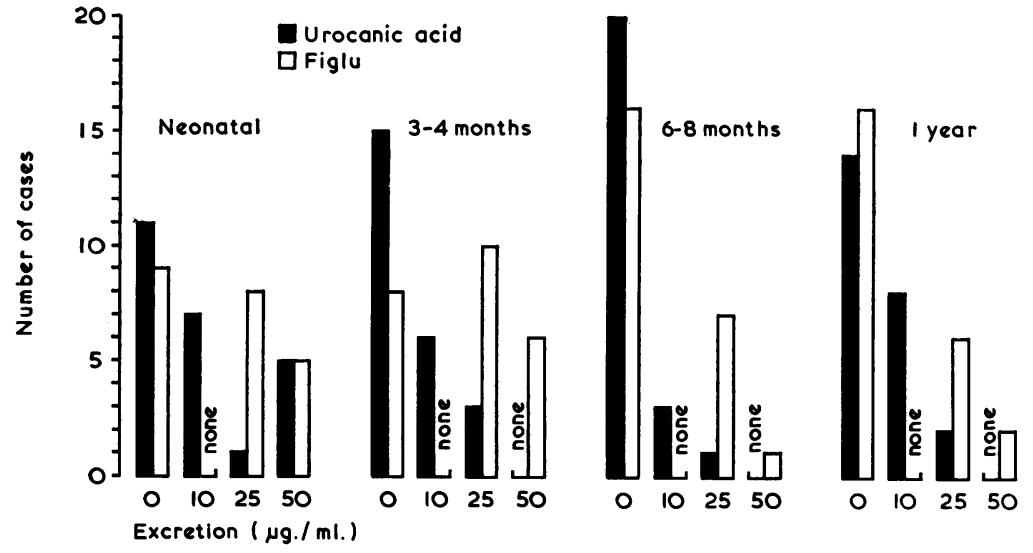

FIG. 6.-Urinary excretion of Figlu and urocanic acid during the first year of life.

kg. bore no relation to the content of metabolites, nor was the behaviour of any infant consistent in this respect at the 4 different times of testing.

As they grew older fewer infants' excreted detectable amounts of Figlu and urocanic acid. This finding contrasts with the falling blood folate levels.

Figlu and urocanic acid excretion were no greater when serum folates were in the 'low' range below $5 \mathrm{~m} \mu \mathrm{g} . / \mathrm{ml}$.

Total figures for Figlu and urocanic acid excretion calculated on the urine volumes obtained did not exceed $6 \mathrm{mg}$. in 6 hours. These figures are similar to those of normal adults in this laboratory.

Neutrophil lobe counts. The average lobe count tended to increase with age. Only 4 infants during the period 6-12 months presented figures slightly above the adult normal (Table II). One had a serum folate of $4 \mathrm{~m} \mu \mathrm{g}$. $/ \mathrm{ml}$., while the others had normal levels. In all 4 the serum B12 was normal. No Figlu or urocanic acid was detectable in their urine. Serum iron was not done, but 2 infants had a mean corpuscular haemoglobin concentration of $29 \%$. Some degree of iron deficiency might account for the hypersegmentation.

Folate intake. Samples of the diet taken by 2 infants at the age of 3 months were assayed. The results are given in Table III. These diets were representative of those of most infants up to the age of 4 months, and indicate that during the first few months $L$. casei active folate intake was below the probable minimum requirement in healthy adults as established by Herbert (1962). Most tinned foods are likely to have a negligible folate content (McCance and Widdowson, 1960), but from the age of 4 months some fresh food including egg-yolk was given to most infants. From the age of 6 months, $60 \%$ of the infants received whole cows' milk which

TABLE II

Results of Investigations on 24 Normal Infants During First Year of Life

\begin{tabular}{|c|c|c|c|c|c|c|c|c|}
\hline \multirow{2}{*}{ Age } & \multirow{2}{*}{$\underset{(\mathrm{kg} .)}{\text { Weight }}$} & \multirow{2}{*}{$\underset{(\mathrm{g} . / 100 \mathrm{ml} .)}{\text { Haemoglobin }}$} & \multirow{2}{*}{$\underset{(\%)}{\operatorname{MCHC}}$} & \multicolumn{3}{|c|}{ Folate (L. casei) (mu.g./ml.) } & \multirow{2}{*}{$\begin{array}{c}\text { Average } \\
\text { Lobe } \\
\text { Count }\end{array}$} & \multirow{2}{*}{$\begin{array}{l}\text { \% Cells } \\
\text { With } 5 \\
\text { or More } \\
\text { Lobes }\end{array}$} \\
\hline & & & & Serum & $\begin{array}{l}\text { Whole } \\
\text { Blood }\end{array}$ & $\begin{array}{c}\text { WB/ml. } \\
\text { RBC }\end{array}$ & & \\
\hline 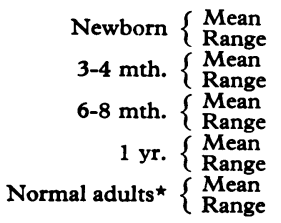 & $\begin{array}{c}3 \cdot 1 \\
2 \cdot 2-4 \cdot 1 \\
6 \cdot 1 \\
4 \cdot 6-7 \cdot 4 \\
7 \cdot 8 \\
6 \cdot 9-10 \cdot 2 \\
10 \cdot 7 \\
9-13\end{array}$ & $\begin{array}{c}17 \cdot 6 \\
14-20 \cdot 8 \\
12 \\
10 \cdot 6-14 \\
11 \cdot 9 \\
10 \cdot 2-13 \cdot 6 \\
11 \cdot 9 \\
10 \cdot 2-13 \cdot 2\end{array}$ & $\begin{array}{c}36 \\
33-38 \\
34 \\
30-36 \\
33 \\
29-36 \\
32 \\
29-34\end{array}$ & $\begin{array}{c}24 \cdot 5 \\
3-59 \\
12 \cdot 2 \\
5-30 \\
7 \cdot 7 \\
3 \cdot 5-16 \\
9 \cdot 3 \\
3-35 \\
13 \cdot 1 \\
7-20\end{array}$ & $\begin{array}{c}315 \\
100-960 \\
99 \\
20-318 \\
77 \\
32-176 \\
86 \\
31-400 \\
195 \\
24 \dagger-400\end{array}$ & $\begin{array}{c}598 \\
196-1256 \\
283 \\
110-489 \\
247 \\
100-466 \\
277 \\
74-995 \\
454 \\
43+-837\end{array}$ & $\begin{array}{c}2 \cdot 35 \\
2 \cdot 12-2 \cdot 79 \\
2 \cdot 56 \\
2 \cdot 28-2 \cdot 93 \\
2 \cdot 64 \\
2 \cdot 40-3 \cdot 21 \\
2 \cdot 81 \\
2 \cdot 55-3 \cdot 21 \\
2 \cdot 66 \\
2 \cdot 37-2 \cdot 90\end{array}$ & $\begin{array}{l}0 \cdot 33 \\
0-3 \\
0 \cdot 58 \\
0-3 \\
0 \cdot 33 \\
0-4 \\
1 \\
0-4 \\
0 \cdot 75 \\
0-3\end{array}$ \\
\hline
\end{tabular}

$\star$ Figures for this laboratory. † These low figures come from the same normal subject. See text. Remaining normal figure $>60 \mathrm{~m} \mu \mathrm{g} . / \mathrm{ml}$. for whole blood, and $>100 \mathrm{mug} . / \mathrm{ml}$. RBC. 
TABLE III

Dietary 'Folate' (L. casei) in Two Infants at the Age of 3 months

\begin{tabular}{|c|c|c|c|c|c|c|c|}
\hline \multirow{2}{*}{ Case No. } & \multirow{2}{*}{ Food } & \multirow{2}{*}{$\begin{array}{l}\text { Quantity } \\
\text { Taken in } \\
24 \text { Hours }\end{array}$} & \multicolumn{3}{|c|}{$\begin{array}{c}\text { Folate (L. casei) Activity } \\
(\mathrm{m} \mu \mathrm{g} . / \mathrm{ml} ., \mathrm{m} \mu \mathrm{g} . / \mathrm{g} .)\end{array}$} & \multirow{2}{*}{$\begin{array}{l}\text { 24-hour } \\
\text { Folate } \\
\text { Intake } \\
(\mu \mathrm{g} .)\end{array}$} & \multirow{2}{*}{$\begin{array}{l}\text { Total } \\
(\mu \mathrm{g} .)\end{array}$} \\
\hline & & & $\begin{array}{c}\text { Before } \\
\text { Charcoal } \\
\text { Absorption }\end{array}$ & $\begin{array}{c}\text { After } \\
\text { Charcoal } \\
\text { Absorption }\end{array}$ & Net & & \\
\hline 1 & $\begin{array}{l}\text { Cow and Gate full cream milk } \\
\text { Scott's baby oats/wheat } \\
\text { Heinz baby food, banana }\end{array}$ & $\begin{array}{l}800 \mathrm{ml} \\
15 \mathrm{~g} . \\
50 \mathrm{~g} .\end{array}$ & $\begin{array}{r}38 \\
495 \\
160\end{array}$ & $\begin{array}{r}12 \\
36 \\
120 \\
\end{array}$ & $\begin{array}{r}26 \\
459 \\
40\end{array}$ & $\begin{array}{c}20 \cdot 8 \\
6 \cdot 9 \\
2\end{array}$ & $29 \cdot 7$ \\
\hline 2 & $\begin{array}{l}\text { Cow and Gate full cream milk } \\
\text { Farex baby ' } 3 \text { cereal' } \\
\text { Heinz baby food, apricot-rice }\end{array}$ & $\begin{array}{l}900 \mathrm{ml} . \\
10 \mathrm{~g} . \\
75 \mathrm{~g} .\end{array}$ & $\begin{array}{r}38 \\
318 \\
120\end{array}$ & $\begin{array}{r}12 \\
12 \\
120\end{array}$ & $\begin{array}{r}26 \\
306 \\
0\end{array}$ & $\begin{array}{c}23 \cdot 5 \\
3 \cdot 1 \\
0\end{array}$ & $26 \cdot 6$ \\
\hline
\end{tabular}

Powdered milk made up in boiled water but not autoclaved or reheated above $37^{\circ} \mathrm{C}$. before feeding.

Naiman and Oski (1964) found to contain more $L$. case $i$ activity than many powdered milks.

\section{Comment}

The newborn infant generally has higher serum and whole blood folate levels than his mother. Our findings agree with those of others (Baker et al., 1960; Grossowicz et al., 1960) in this respect, though prophylactic folic acid given to the mothers in this series resulted in less difference between maternal and neonatal levels. There was no direct relation between individual maternal and neonatal levels, nor did individual neonatal levels appear to influence subsequent levels during the first year of life (Fig. 3).

The fall in serum and whole blood levels during the first year follows the pattern found by Matoth, Pinkas, Zamir, Mooallem, and Grossowicz (1964a) for whole blood in normal children in Israel. The higher levels in the 2 infants of this series who were breast fed is in accord with the findings of Matoth, Pinkas, and Sroka (1965).

In contrast to the falling folate levels, urinary excretion of Figlu and urocanic acid diminish during the first year. This seems to indicate that in normal well infants folate stores are sufficient to handle a histidine load. The slightly greater excretion of metabolites in the first few months of life may reflect some degree of liver immaturity.

It is probably fair to say that the lower serum and whole blood folate values in infants reflect lower folate stores. The minimal daily folate requirement for a healthy adult is of the order of $50 \mu \mathrm{g}$. (Herbert, 1962). Extrapolation of this figure in terms of weight or surface area cannot be valid in an infant who is doubling his weight in 6 months and trebling it in a year. An estimate of folate intake in the diet of 2 infants at the age of 3 months indicates that this may often be less than $50 \mu \mathrm{g}$./day. Different ways of preparing different milk products and individual variation in diet will of course result in a wide scatter of folate intake during the first year.

We are assuming that $L$. casei active folate in food is of major importance, and the reservations made by Naiman and Oski (1964) concerning 'food folate' apply to our figures.

That folate stores are marginal during infancy seems indicated by the high proportion of children in hospital with abnormal Figlu tests (Dormandy et al., 1963; Frézal et al., 1964) and the comparatively high incidence of megaloblastic anaemia in sick children (Matoth, Zamir, Bar-Shani, and Grossowicz, 1964b; Friedman, McKenzie, Turner, and Wittmann, 1964b). Under the extra stress of illness and with concomitant reduction in folate intake or absorption the deficiency may rapidly become overt.

\section{Summary}

Twenty-four normal full-term London infants were followed up during the first year of life in order to establish normal values for parameters related to folic acid metabolism, and to determine whether by adult standards there was evidence of folic acid deficiency in this age-group. After the third month mean values for serum and whole blood folate were lower than in adults. Figlu and urocanic acid excretion were of the same order as in normal adults, providing the histidine load did not exceed $300 \mathrm{mg} . / \mathrm{kg}$. It is recommended that this load should not be exceeded.

Marginal folate stores during the first year are probably related to an intake that is barely adequate to meet the needs of rapid growth. This may result in the rapid development of overt deficiency during illness.

The co-operation of many people was necessary for this study, and we are particularly grateful for the help received from Miss R. Harris, Superintendent Midwife, and Miss M. Munro, Sister-in-charge of the Mothercraft Department, and their staffs. 
Our thanks are due also to Dr. D. Cottom and Dr. B. D. R. Wilson for permission to study infants under their care, and to Miss Dewe, hospital artist, for Fig. 4 and 5.

Last but not least we thank the mothers and infants who made the study possible.

\section{REFERENCES}

Baker, H., Frank, O., Pasher, I., Ziffer, H., and Sobotka, H. (1960) Pantothenic acid, thiamine and folic acid levels at parturition. Proc. Soc. exp. Biol. (N.Y.), 103, 321.

Butterworth, C. E., Jr., Santini, R., Jr., and Frommeyer, W. B., Jr. (1963). The pteroylglutamate components of American diets as determined by chromatographic fractionation. $\mathcal{F}$. clin. Invest., 42, 1929.

Chanarin, I., and Berry, V. (1964). Estimation of serum L. casei activity. $\mathcal{F}$. clin. Path., 17, 111.

Dormandy, K. M., Waters, A. H., and Mollin, D. L. (1963). Folicacid deficiency in coeliac disease. Lancet, 1, 632

Frézal, J., Rey, J., Jarlier, H., and Lamy, M. (1964). L'excrétion de l'acide formino-glutamique (FIGLU) chez le nourrisson 'normal' et dans les stéatorrhées par trouble de l'absorbtion intestinale. Rev. franc. Étud. clin. biol., 9, 38.

Friedman, R., McKenzie, D., Turner, T., and Wittmann, W. (1964a). An assessment of the histidine-loading (FIGLU) test in infancy. S. Afr. f. Lab. clin. Med., 10, 67.

$\longrightarrow,-$, and $\longrightarrow$ (1964b). Folic-acid deficiency in infantile gastro-enteritis. ibid., 10, 69.

Grossowicz, N., Aronovitch, J., Rachmilewitz, M., Izak, G., Sadousky, A., and Bercouici, B. (1960). Folic and folinic acid in maternal and foetal blood. Brit. F. Haemat., 6, 296.
Hansen, H. A. (1964). On the Diagnosis of Folic Acid Deficiency. Almqvist \& Wiksell, Stockholm.

Herbert, V. (1961). The assay and nature of folic acid activity in human serum. F. clin. Invest., 40, 81 .

- (1962). Minimal daily adult folate requirement. Arch. intern. Med., 110, 649.

Knowles, J. P., Prankerd, T. A. J., and Westall, R. G. (1960). Simplified method for detecting formiminoglutamic acid in urine as a test of folic-acid deficiency. Lancet, 2, 347.

McCance, R. A., and Widdowson, E. M. (1960). The composition of foods. Spec. Rep. Ser. med. Res. Coun. (Lond.), No. 297.

Matoth, Y., Pinkas, A., and Sroka, C. (1965). Studies on folic acid in infancy. III. Folates in breast fed infants and their mothers. Amer. F. clin. Nutr., 16, 356.

- - Z Zamir, R., Mooallem, F., and Grossowicz, N. (1964a). Studies on folic acid in infancy. I. Blood levels of folic and folinic acid in healthy infants. Pediatrics, 33, 507.

- Zamir, R., Bar-Shani, S., and Grossowicz, N. (1964b). Studies on folic acid in infancy. II. Folic and folinic acid blood levels in infants with diarrhea, malnutrition, and infection. ibid., 33, 694.

Naiman, J. L., and Oski, F. A. (1964). The folic acid content of milk: revised figures based on an improved assay method. ibid., 34, 274.

Snell, E. E., and Peterson, W. H. (1940). Growth factors for bacteria. $\mathrm{X}$. Additional factors required by certain lactic acid bacteria. F. Bact., 39, 273.

Vanier, T. M., and Tyas, J. F. (1966). The effect of prophylactic folic acid on serum and whole blood levels during the last trimester of pregnancy. $\mathcal{f}$. Obstet. Gynaec. Brit. Cwlth. In the press. 